\title{
Simultaneous Prenatal Ethanol and Nicotine Exposure Affect Ethanol Consumption, Ethanol Preference and Oxytocin Receptor Binding in Adolescent and Adult Rats
}

\author{
Sarah K. Williams ${ }^{1}$, Elizabeth T. Cox ${ }^{1}$, Matthew S. McMurray ${ }^{2}$, Emily E. Fay ${ }^{2}$, Thomas M. \\ Jarrett $^{1,3}$, Cheryl H. Walker ${ }^{4}$, David H. Overstreet ${ }^{4,5}$, and Josephine M. Johns ${ }^{1,2,4,5}$ \\ ${ }^{1}$ Curriculum in Neurobiology The University of North Carolina at Chapel Hill, Chapel Hill NC, 27599 \\ 2 Department of Psychology The University of North Carolina at Chapel Hill, Chapel Hill NC, 27599 \\ ${ }^{3}$ School of Medicine The University of North Carolina at Chapel Hill, Chapel Hill NC, 27599 \\ ${ }^{4}$ Department of Psychiatry The University of North Carolina at Chapel Hill, Chapel Hill NC, 27599 \\ ${ }^{5}$ Bowles Center for Alcohol Studies The University of North Carolina at Chapel Hill, Chapel Hill NC, \\ 27599
}

\begin{abstract}
Ethanol consumption and smoking during pregnancy are common, despite the known adverse effects on the fetus. The teratogenicity of each drug independently is well established; however, the effects of concurrent exposure to ethanol and nicotine in preclinical models remain unclear. This study examined the impact of simultaneous prenatal exposure to both ethanol and nicotine on offspring ethanol preference behaviors and oxytocin system dynamics. Rat dams were given liquid diet (17\% ethanol derived calories(EDC)) on gestational day (GD) 5 and 35\% EDC fromGD 6-20 and concurrently an osmotic minipump delivered nicotine (3-6 mg/kg/day) from GD 4 - postpartum day 10. Offspring were tested for ethanol preference during adolescence (postnatal day (PND) 30-43) and again at adulthood (PND 60-73), followed by assays for oxytocin mRNA expression and receptor binding in relevant brain regions. Prenatal exposure decreased ethanol preference in males during adolescence, and decreased consumption and preference in females during adulthood compared to controls. Oxytocin receptor binding in the nucleus accumbens and hippocampus was increased in adult prenatally exposed males only. Prenatal exposure to these drugs sex-specifically decreased ethanol preference behavior in offspring unlike reports for either drug separately. The possible role of oxytocin in reduction of ethanol consumption behavior is highlighted.
\end{abstract}

\section{Keywords}

Prenatal Alcohol; Prenatal Nicotine; Oxytocin; Two-Bottle Choice; Adolescence

() 2009 Elsevier Inc. All rights reserved.

Corresponding Author: Sarah Williams 436 Taylor Hall CB\# 7096 University of North Carolina at Chapel Hill Chapel Hill, NC, USA 27599 Phone: +1 9199665961 Fax: +1 9198435730 sarahk_williams@med.unc.edu.

Publisher's Disclaimer: This is a PDF file of an unedited manuscript that has been accepted for publication. As a service to our customers we are providing this early version of the manuscript. The manuscript will undergo copyediting, typesetting, and review of the resulting proof before it is published in its final citable form. Please note that during the production process errors may be discovered which could affect the content, and all legal disclaimers that apply to the journal pertain.

Conflicts of Interest

The authors do not have any conflicts of interest regarding this work. 


\section{Introduction}

Approximately $20 \%$ of the U.S. adult population report concurrent use of ethanol and nicotine [20,52]. Fetal drug exposure to ethanol and nicotine is of particular concern as at least $12 \%$ of women report ethanol consumption during pregnancy [10,52] and $13-21 \%$ of pregnant women report smoking cigarettes $[26,27,52]$, despite the public health campaigns targeting prevention of these behaviors. Additionally, $50 \%$ of women of childbearing age report drinking or smoking on a regular basis [52] and since recent reports indicate that half of pregnancies are unplanned [21] these women may not be aware of their pregnancy until the fetus is inadvertently exposed to these substances for several months.

An estimated 1\% of children born in the United States exhibit symptoms of fetal ethanol exposure [41]. In addition to physically teratological effects (for reviews see [25,51]), in utero exposure to ethanol can result in greater ethanol use in adolescence, including a higher number of drinks per occasion, earlier age at first intoxication, and ethanol dependence [5]. Similarly, prenatal nicotine exposure has been shown to cause preterm birth, low birth weight [19] and increased adolescent nicotine self-administration in rodents [34,66]. Maternal nicotine use through cigarette smoking is often accompanied by concurrent ethanol consumption; however, there are few systematic studies of the effects of prenatal exposure to simultaneous use or treatment with these drugs. Recently, it was reported that prenatal exposure to both ethanol and nicotine in rats increased nicotine self-administration similarly to either nicotine or ethanol exposure during adolescence [40]. Additionally, we have shown that simultaneous prenatal exposure to ethanol and nicotine increased the sex differences in ethanol consumption during adolescence[45].

Adolescent drug consumption following prenatal exposure is particularly significant to study as reports from both clinical and preclinical models have shown that adolescent ethanol use is associated with higher levels of adult ethanol use $[12,59,60]$. Sex differences in drinking behavior are apparent during both adolescence and adulthood [3,16,52,60], and since the adolescent brain and behavior differ radically from adults, especially in females who have not yet started or have just begun to menstruate, sex-based differences in ethanol consumption should be considered. We have recently reported sex-specific differences in adolescent twobottle choice ethanol consumption following prenatal exposure to both ethanol and nicotine [45] and this study, as an extension of the prior study, aims to determine if prenatal exposure impacts the priming effect of adolescent drinking on adult drinking.

Oxytocin (OT), a hypothalamic neuropeptide, is known primarily for its role in many social/ affiliative interactions and modulation of the stress response in clinical populations and preclinical models [38,74]. OT has long been implicated in drug abuse [35] and a revitalization of the study of OT in drug consumption behavior is ongoing [44]. Recent work has shown that plasma levels of OT are affected by alcohol consumption in adult nulliparous and lactating women [46,47]. Changes in OT signaling in brain regions associated specifically with reward, including the ventral tegmental area, nucleus accumbens, hippocampus, and amygdala [24], may play a significant role in the development of behavioral tolerance to alcohol [35]; however, its role in ethanol drinking behavior is unclear. We recently reported that combined exposure to ethanol and nicotine was associated with lower OT levels in several brain regions associated with reward in adult male offspring following two-bottle choice ethanol consumption [45]. This study further investigates how OT system dynamics are associated with ethanol drinking behavior.

The present study is an extension of previous work utilizing concurrent developmental exposure to ethanol and nicotine in a rodent model that demonstrated sex-specific effects on ethanol consumption when tested either during adolescence or adulthood that were associated 
with changes in OT levels in the ventral tegmental area. Here, we examined the effects of prenatal exposure to ethanol and nicotine on subsequent ethanol consumption and preference during both adolescence and adulthood in male and female offspring. Additionally, OT mRNA expression and OT receptor binding were examined in offspring brain regions relevant to reward and drinking behavior following behavioral testing. Importantly, it was determined in prior comparisons of maternal behavior of drug treated dams and controls rearing surrogate pups, that there were minimal effects of ethanol/nicotine treatment on non pup-directed maternal behaviors typically thought to be most important for pup development [22,36]. Thus, in the present study offspring were reared by their natural dams. We hypothesized that ethanol preference and consumption would be increased by combined prenatal exposure to ethanol and nicotine in a sex-specific manner during both adolescence and adulthood. We predicted that an increase in ethanol preference would coincide with a decrease in OT production and/or receptor binding in brain areas associated with drinking behavior and reward.

\section{Materials and Methods}

\subsection{Animals}

All procedures were approved by the UNC-Chapel Hill Institutional Animal Care and Use Committee, and were completed in AAALAC approved animal facilities and behavioral observation rooms. Thirty six virgin Sprague-Dawley rats (Charles River, Raleigh, NC) were paired with single males until the presence of a sperm plug or a vaginal smear confirmed pregnancy, designated as gestational day (GD) zero. Pregnant dams were randomly assigned to one of two groups: either a combined ethanol liquid diet/nicotine osmotic pump (E/N; n=19) or vehicle (control liquid diet and vehicle pump; $n=17$ ) treatment. Dams were singly housed in a reverse $12 \mathrm{hr}$ light cycle for the first seven days (lights out at 9:00 AM) then switched to a normal light cycle (lights on at 7:00 AM), resulting in delivery during the daylight hours [42]. Although photoperiod reversal can impact neurobiological systems [13], these are experienced by both groups, and pilot studies indicated that a photoperiod change at this point in gestation does not affect dam behavior. All dams had ad libitum access to water throughout the study. From GD one through four, $100 \mathrm{~mL}$ of control liquid diet (LD82, Shake and Pour: Bio-Serv, Frenchtown, NJ) was given to all dams to habituate them to liquid diet. Five dams from each group were removed from the study because of complications of surgery or loss of pregnancy, resulting in 12-14 litters from each group.

\subsection{Gestational Drug Treatment}

2.2.1 Ethanol-During GDs 5-20, E/N dams received $100 \mathrm{~mL}$ of ethanol liquid diet [LD82, Shake and Pour-Ethanol: Bio-Serv, Frenchtown, NJ and 95\% ethanol (Aaper Alcohol, Shelbyville, KY)] daily. E/N dams were first introduced to a diet containing $17.5 \%$ ethanolderived calories (EDC) on GD 5 and then given a diet containing 35\% EDC on GD 6 through 20. Immediately following birth (GD 21), all dams were switched to pellet diet (Purina Rat Chow), as pilot work indicated pup survival was compromised if ethanol diet was maintained through postpartum period (while still receiving nicotine). Vehicle-treated dams received control liquid diet throughout gestation (LD82, Shake and Pour-Control: Bio-Serv, Frenchtown, NJ). To control for the anorectic effects of ethanol and nicotine throughout gestation, vehicle dams were food-yoked to the mean liquid diet consumption of $\mathrm{E} / \mathrm{N}$ dams from GDs 5 to 21 . A chow fed only group was not used in this specific follow-up study as we reported appreciable differences in later offspring ethanol preference from drug exposed and control diet exposed pups reared by surrogate pair-fed dams indicating treatment alone effects on drinking [45].

2.2.2 Nicotine-On the morning of GD four (before embryo implantation), all dams were surgically implanted with an osmotic minipump (Alzet: 2ML4, Durect, Cupertino, CA) 
containing bacteriostatic water (Abbott Diagnostics, Abbott Park, IL) and either nicotine hydrogen tartrate (Sigma Chemical, St. Louis, MO) for E/N dams or sodium bitartrate vehicle (Fischer Scientific, Pittsburgh, PA) for controls. Animals were anesthetized with ether, a small incision was made in the flank of the dam, and the pump inserted. The wound was sealed with wound clips and bupivacaine (Fischer Scientific, Pittsburgh, PA) was administered to the wound site. Animals were allowed to recover for 30 minutes under heat lamps and returned to their cage. Topical antibiotic ointment (bacitracin zinc and polymycin B sulfate, Fougera Melville, NY) was applied daily to minimize infection. Wound clips were removed on GD 14. The minipump delivered drug for approximately 28-30 days (through PPD 10-12) at a constant dose of approximately $1.5 \mathrm{mg} / \mathrm{day}$. This resulted in a decreasing $\mathrm{mg} / \mathrm{kg} /$ day effective dose throughout gestation as dam weight and fetal growth increased. Initially, each dam received approximately $6 \mathrm{mg} / \mathrm{kg} / \mathrm{day}$, by parturition received approximately $3 \mathrm{mg} / \mathrm{kg} / \mathrm{day}$, and during lactation approximately $3.5 \mathrm{mg} / \mathrm{kg} / \mathrm{day}$. Although removal of the pump when ethanol diet was terminated would have been optimal, surgical removal of the pump following parturition would have required several days of recovery, during which the pups would have been removed from the dam. This was considered more disruptive than the effects of this dose of nicotine during this period of development on our measures. This route mimics nicotine intake patterns of human users who maintain the number of cigarettes smoked (and thus their nicotine dose) per day throughout pregnancy and the postpartum period [48]. Dams receiving nicotine filled pumps began ethanol diet the following day (see above), while dams receiving sodium bitartrate continued to receive control liquid diet.

\subsection{Blood Ethanol Concentration Assessment}

Blood ethanol concentration (BEC) was measured for all dams (both $\mathrm{E} / \mathrm{N}$ and vehicle groups) on GD 15 at approximately 7:15 AM (immediately following the dark cycle) and analyzed as described previously [45]. Tail blood samples were collected in heparin and stored at $4{ }^{\circ} \mathrm{C}$ until measurement. Blood and standards (0-300 $\mathrm{mg} \%$ ) were mixed with distilled water and $\mathrm{NaCl}$ in borosilicate glass tubes. Tubes were then capped and heated to $55^{\circ} \mathrm{C}$, and headspace gas was injected directly into an SRI 8610C gas chromatograph (Torrance, CA). Areas under the curve were analyzed with SRI PeakSimple. E/N treatment in dams resulted in average BECs of $105.5 \pm 14.5 \mathrm{mg} \% / \mathrm{dl}$.

\subsection{Offspring Ethanol Preference}

2.4.1 Offspring Selection and Treatment-Litters were culled to eight pups (four male, four female) at birth and weaned on postnatal day (PND) 21 into same sex groups of four. Pups were reared by their own biological dams as previous maternal behavior testing using this treatment paradigm indicated only minor effects on early non-pup directed specific behaviors (pup-directed behaviors of licking and nursing were unaffected) by treatment dams versus control dams on postpartum day one [45]. Licking and nursing behaviors are known to play a large role in infant development [22,36], and as these were unaffected and rearing by biological mothers during the neonatal period in humans is the rule rather than the exception, using biological dam rearing was a stronger translational model for this study. To avoid litter effects, one male and one female from each $\mathrm{E} / \mathrm{N}$ and vehicle litter were randomly selected to undergo ethanol preference assessment beginning during adolescence (PNDs 29-43) and the same animals were tested again during early adulthood (PNDs 59-73). The timeline with procedures for ethanol preference phases is detailed for both adolescent and adult testing in Figure 1. Individual offspring weights were recorded every three days during testing. During habituation for cage bottle presence, two graduated cylinders containing tap water were placed at the front of the cage for 24 hours before any testing was initiated. For all preference testing, two solutions were simultaneously presented in plastic $100 \mathrm{~mL}$ graduated cylinder tubes with rubber stoppers and metal sippers (Fischer Scientific International Inc., NH). Ethanol (95\% Aaper Alcohol, Shelbyville, KY) or $0.1 \%$ sodium saccharin salt (Acros Organics, New Jersey) were diluted 
with tap water. To control for side preferences, the cylinders were alternated daily and 24 hour fluid consumption from all tubes was recorded daily (approximately 9:00 AM) for each animal.

2.4.2 Ethanol Preference Procedures-Prior to the ethanol acquisition phase, a saccharin-water choice test (unlimited access to either $0.1 \%$ saccharin or tap water) was used to assess sweet preference. Preference for sweet solutions is used to ensure taste perception has not been altered and preference for sweet solutions has been tied to ethanol preference [33]. The Acquisition phase entailed a choice between two bottles containing increasing amounts of ethanol or water; and the Two-Bottle Choice period assessed preference for high ethanol concentration (10\%) over water. The Forced Consumption phase is an important step to reduce variability of ethanol consumption during the Two-Bottle Choice phase. The voluntary consumption behavior inherent in two-bottle choice testing procedures allows the opportunity for some animals to never spontaneously consume the ethanol solution during Acquisition, and the Forced Consumption stage of the procedure ensures pharmacologically relevant amounts of ethanol were consumed because only ethanol solution is available [56].

\subsection{Tissue Collection}

Offspring were killed within an hour of test completion on PND 73. Subjects were decapitated and whole brains flash frozen and stored at $-80^{\circ} \mathrm{C}$. Brains were sequentially sliced on a cryostat (Leica CM 3050, Germany) at 20 $\mu$ m thickness. Slices were thaw mounted onto Superfrost Plus slides (Fisher Scientific International Inc., $\mathrm{NH}$ ) and returned to storage at $-80^{\circ} \mathrm{C}$ until time of assay. Every tenth slide was stained using thionin (Fischer Scientific, Fair Lawn, NJ) for region identification aided by the rat brain atlas [57] and are represented as anterior to posterior Bregma designations below. Randomly chosen representative slides for oxytocin mRNA in situ hybridization came from the paraventricular $[-1.40$ to $-2.12 \mathrm{~mm}]$ and supraoptic $[-1.20$ to $-1.80 \mathrm{~mm}$ ] nuclei of the hypothalamus. Representative slides were randomly selected from each animal to assess oxytocin receptor binding in the nucleus accumbens and caudate putamen [2.70 to $0.70 \mathrm{~mm}$ ], bed nucleus of the stria terminalis [ -0.26 to $-0.96 \mathrm{~mm}$ ], ventromedial hypothalamus and amygdala [ -2.12 to $-3.14 \mathrm{~mm}$ ], posterior CA3 and CA1 regions of the hippocampus [ -4.16 to $-6.04 \mathrm{~mm}]$, and ventral tegmental area [ -5.20 to $-6.04 \mathrm{~mm}$.

\subsection{Oxytocin In Situ Hybridization}

OT in situ hybridization was performed on 8-16 sections from the supraoptic nucleus or paraventricular nucleus using a single, 41 base, ${ }^{35}$ S-oligonucleotide probe (GGG CTC AGC GCT CGG AGA AGG CAG ACT CAG GGT CGC AGG CG) complementary to nucleotides 906-946 of the rat OT mRNA (GenBank Accession Number K01701). Sections were processed for OT in situ hybridization as described previously [30,71], with slight modifications for this study. Briefly, sections were fixed in $4 \%$ paraformaldehyde and rinsed in phosphate-buffered saline. Then they were rinsed in $1.5 \%$ triethanolamine and treated with $0.25 \%$ acetic anhydride, defatted in chloroform and dehydrated in a series of graded concentrations of ethanol. Each slide was incubated at $37{ }^{\circ} \mathrm{C}$ overnight with $200 \mu \mathrm{l}$ of hybridization solution (50\% formamide, 1 - Denhardt's solution, $10 \%$ dextran sulfate, $0.3 \mathrm{M}$ $\mathrm{NaCl}, 0.8$. Tris/EDTA, $8 \mathrm{mM}$ dithiothreitol and $1 \mathrm{mg} / \mathrm{ml}$ tRNA) containing about $1 \cdot 106 \mathrm{cpm}$ of oxytocin oligonucleotide probe which was labeled with ${ }^{35} \mathrm{~S}$ dATP (Perkin-Elmer, MA) using Tdt and purified with a QiaQuick nucleotide removal kit (Qiagen, CA). After the incubation, the slides were washed in saline-sodium citrate buffer, dehydrated with ethanol/ ammonium acetate, and dried. Slides were placed on Biomax MR Film (Kodak, NY) for 60 min and developed. Specificity controls included treating sections with a sense probe for the OT peptide during probe development, which did not produce any labeling. 


\subsection{Oxytocin Receptor Autoradiography}

Oxytocin receptor binding was assessed on 8-16 sections from each region of interest. Autoradiography was performed using ${ }^{125} \mathrm{I}$-OTA $\left[\mathrm{d}\left(\mathrm{CH}_{2}\right)_{5}, \mathrm{O}-\mathrm{Me}-\mathrm{Tyr}^{2}, \mathrm{Thr}^{4}, \mathrm{Tyr}^{9}, \mathrm{Orn}^{8}\right]-$ vasotocin (Perkin Elmer, Boston, MA) as described previously [23]. Sections were allowed to thaw at room temperature, immersed in $0.1 \%$ paraformaldehyde at room temperature for two minutes, and then rinsed twice for 10 minutes in Tris Buffer. For tracer binding, $30 \mathrm{~mL}$ of tracer solution containing $1,800 \mathrm{cpm} / 10 \mu \mathrm{l}$ probe was applied to the sections in vertical slide holders at room temperature for 60 minutes. After tracer binding, the slides underwent three five-minute washes with Tris/ $\mathrm{MgCl}$ buffer at room temperature, followed by one 30-minute wash in Tris/ $\mathrm{MgCl}$ buffer, and then a final two-second wash in distilled water. Slides were then rapidly dried and, along with a series of ${ }^{125} \mathrm{I}$-microscale standards, were exposed on film for three days to obtain images for quantification.

\subsection{Photomicrograph Production and Image Analysis}

Images were quantified bilaterally from 8-16 sections per region, per animal using digitized films and the NIH Image program for the Macintosh ${ }^{\circledR}$. If fewer than 8 sections could be quantified, then that animal was not included in the analysis (2-3 animals from each group for each brain region). For the receptor binding studies, optical densities were converted to disintegrations per minute (dpm), per milligram tissue equivalents using the ${ }^{125} \mathrm{I}$ autoradiograph standards developed with the slide images, with the exception of the VTA where binding was too low to quantify using the standards. This conversion was not used on the mRNA film, since standards are not commercially available. For in situ hybridization analysis, comparisons between treatment groups were based on optical density measurements.

\section{9 Statistical Analysis}

Maternal gestational variables, including number of pups per litter, number stillborn, litter weight, culled litter weight, litter sex ratio, gestational length, and gestational weight gain were compared using Student's $t$ - tests with Bonferroni adjusted probabilites to control for multiple comparisons. Individual offspring weights and weight gain were examined using a two-way (sex by treatment) Analysis of Variance (ANOVA) with post-hoc Tukey tests. Due to the longitudinal design of study and the non-normality of the data (described by a Poisson distribution), data from ethanol preference procedures were analyzed using generalized estimating equations (GEE) [76], which results in a series of test statistics with a Chi-squared $\left(\chi^{2}\right)$ distribution under the null hypothesis (for application review, see [29]). GEEs using repeated measures additive models with contrasts to assess specific hypotheses examined total liquid volume $(\mathrm{mL})$ consumed, water consumed in grams per kilogram per day $(\mathrm{g} / \mathrm{kg} / \mathrm{day})$, ethanol consumed $(\mathrm{g} / \mathrm{kg} / \mathrm{day})$, and saccharin and ethanol preference. Preference was operationally defined as percent ethanol (or saccharin) solution of total volume consumed (\%) using the equation below:

[Mixed solution consumed (mL)/ Total Liquid (Water + Mixed Solution)] *100 Oxytocin receptor binding and oxytocin mRNA levels in each brain region were examined using generalized linear models. Alpha levels for all tests were set to 0.05. All results in figures are presented as means \pm SEM for every day of testing.

\section{Results}

\subsection{Gestational and Offspring Growth Data}

Table 1 presents gestational results demonstrating that there were no between-group differences in the number of pups per litter, number of stillborn pups, gestational length, or sex ratio. $\mathrm{E} / \mathrm{N}$ treated dams gained less weight than vehicle-treated dams during pregnancy $(\mathrm{t}=8.02$, 
$\mathrm{p} \leq 0.01)$ and $\mathrm{E} / \mathrm{N}$ exposed litters weighed less than vehicle-exposed litters at birth $(\mathrm{t}=4.79, \mathrm{p} \leq$ 0.01 ). Table 2 presents individual offspring weights from adolescence through adulthood. As expected, all males regardless of treatment weighed more than females by PND $43[F(1,27)=$ 49.55, $\mathrm{p} \leq 0.01]$ and PND $73[\mathrm{~F}(1,27)=257.53, \mathrm{p} \leq 0.01]$ and had greater weight gain during adolescence $[\mathrm{F}(1,27)=107.74, \mathrm{p} \leq 0.01]$ and adulthood $[\mathrm{F}(1,27)=72.31, \mathrm{p} \leq 0.01] . \mathrm{E} / \mathrm{N}$ offspring weighed less at PND $30[\mathrm{~F}(1,27)=9.97, \mathrm{p} \leq 0.01]$ and PND $73[\mathrm{~F}(1,27)=15.06, \mathrm{p} \leq$ $0.01]$ and gained less weight during adolescence $[\mathrm{F}(1,27)=4.252, \mathrm{p} \leq 0.05]$ and adulthood $[\mathrm{F}$ $(1,27)=7.255, \mathrm{p} \leq 0.01]$.

\subsection{Offspring Ethanol Consumption and Preference}

Results are presented as between group comparisons during adolescence, then adulthood, followed by within-group age comparisons. Results are discussed by testing period (Acquisition, Forced Consumption, and Two-Bottle Choice). Ethanol and water consumption data refer to the amount ingested (Figures 2,3, and 4) while preference is a comparison of ethanol solution to total solution ingested (Table 3).

3.2.1 Adolescence-There were no differences in saccharin preference (presented as percentages (\%); see Methods) on PND 30 [E/N females (85.3 \pm 8.1 ); E/N males (86.7 \pm 9.7$)$; vehicle-treated females $(89.4 \pm 5.4)$; and vehicle-treated males $(98.5 \pm 1.5)]$. Effects of treatment exposure on adolescent consumption (ethanol and water) compared to control condition exposure are shown in Figure 2.

3.2.1.1 Acquisition: During the acquisition phase (PND 31-35) vehicle-treated males showed a higher ethanol preference compared to $E / N$ males $\left(\chi^{2}=5.81, \mathrm{p} \leq 0.05\right.$, see Table 3$)$ while consuming less water than $\mathrm{E} / \mathrm{N}$ males $\left(\chi^{2}=8.37, \mathrm{p} \leq 0.01\right)$ and vehicle-treated females $\left(\chi^{2}=3.84\right.$, $\mathrm{p} \leq 0.05)$.

3.2.1.2 Forced Consumption: There were no effects on ethanol consumption during the forced consumption phase (PND 36-38), although $\mathrm{E} / \mathrm{N}$ offspring consumed less total liquid than did vehicle-treated offspring $\left(\chi^{2}=15.41, \mathrm{p} \leq 0.01\right)$.

3.2.1.3 Two-Bottle Choice: During the subsequent two-bottle choice phase (PND 39-43), there were no effects of sex or prenatal exposure on ethanol consumption or preference. However, $\mathrm{E} / \mathrm{N}$ offspring drank more water than vehicle-treated offspring $\left(\chi^{2}=25.17, \mathrm{p} \leq 0.01\right)$, and females consumed more water than males from both treatment groups $\left(\chi^{2}=7.66, p \leq 0.01\right)$.

3.2.2 Early Adulthood-There were no differences in saccharin preference (presented as percentages (\%); see Methods) on PND 60 [E/N females (94.6 \pm 2.3 ); E/N males (94.1 \pm 3.3 ); vehicle-treated females $(96.9 \pm 1.9)$; and vehicle-treated males $(100 \pm 0.0)]$. Adult ethanol and water consumption can be seen in Figure 3.

3.2.2.1 Acquisition: During the acquisition phase (PND 61-65), vehicle-treated females consumed more ethanol compared to $\mathrm{E} / \mathrm{N}$ females $\left(\chi^{2}=5.79, \mathrm{p} \leq 0.01\right)$, vehicle-treated males $\left(\chi^{2}=5.33, p \leq 0.05\right)$, and $\mathrm{E} / \mathrm{N}$ males $\left(\chi^{2}=6.53, \mathrm{p} \leq 0.05\right)$. Vehicle-treated females also showed a higher preference for ethanol than $\mathrm{E} / \mathrm{N}$ females during the acquisition phase $\left(\chi^{2}=6.87, \mathrm{p} \leq 0.01\right.$, see Table 3$)$. In addition, all $\mathrm{E} / \mathrm{N}$ offspring consumed more water compared to vehicle-treated offspring $\left(\chi^{2}=20.95, \mathrm{p} \leq 0.01\right)$.

3.2.2.2 Forced Consumption: During the forced consumption phase (PND 66-68), no differences were observed between groups on any measure. 
3.2.2.3 Two-Bottle Choice: During the two-bottle choice phase (PND 69-73), vehicle-treated females consumed more ethanol compared to both $\mathrm{E} / \mathrm{N}$ females $\left(\chi^{2}=5.58, \mathrm{p} \leq 0.01\right)$ and vehicletreated males $\left(\chi^{2}=3.89, \mathrm{p} \leq 0.05\right)$. Vehicle-treated females also displayed a greater ethanol preference compared to $\mathrm{E} / \mathrm{N}$ females $\left(\chi^{2}=5.96, \mathrm{p} \leq 0.01\right)$ and vehicle-treated males $\left(\chi^{2}=4.09\right.$, $\mathrm{p} \leq 0.05)$. E/N offspring of both sexes consumed more water than vehicle-treated offspring $\left(\chi^{2}=20.03, p \leq 0.01\right)$.

3.2.3 Within-Group Age Comparison-Comparisons between adolescent and adult ethanol consumption are shown in Figure 4.

3.2.3.1 Acquisition: During the acquisition phase of testing, adult ethanol preference was also lower than during adolescence $(\mathrm{p} \leq 0.01)$ in $\mathrm{E} / \mathrm{N}$ females $\left(\chi^{2}=5.31\right), \mathrm{E} / \mathrm{N}$ males $\left(\chi^{2}=8.21\right)$, and vehicle-treated males $\left(\chi^{2}=11.00\right)$. Adult rates of ethanol consumption were significantly lower $(\mathrm{p} \leq 0.01)$ compared to adolescence in $\mathrm{E} / \mathrm{N}$ females $\left(\chi^{2}=8.12\right)$, $\mathrm{E} / \mathrm{N}$ males $\left(\chi^{2}=9.33\right)$, and vehicle-treated males $\left(\chi^{2}=19.04\right)$. Vehicle-treated females did not differ in consumption from adolescence to adulthood.

3.2.3.2 Forced Consumption: During the forced consumption phase, a decrease $(p \leq 0.01)$ was seen in adult ethanol consumption compared to adolescent consumption in all groups (E/N females: $\chi^{2}=6.45$ ); (E/N males: $\chi^{2}=26.86$ ); (vehicle-treated females: $\left.\chi^{2}=6.58\right)$; (vehicletreated males: $\chi^{2}=72.19$ ).

3.2.3.3 Two-Bottle Choice: There were no age differences observed during the two-bottle choice period on any measure.

\subsection{Oxytocin In Situ Hybridization}

Figure 5 shows the regions from which OT mRNA results were measured, representative sections from each group and quantification of hybridization. There were no treatment or sex effects on oxytocin mRNA expression in the PVN or SON.

\subsection{Oxytocin Receptor Autoradiography}

Figure 6 presents the means \pm SEM for receptor binding in the regions with significant differences. ANOVAs indicated a sex by treatment interaction in the nucleus accumbens $[\mathrm{F}$ $(1,38)=3.36, p \leq 0.05]$ and the CA3 region of the hippocampus $[F(1,17)=5.82, p \leq 0.05]$. Posthoc Tukey tests revealed that E/N males had higher levels of OT receptor binding than all other groups in the nucleus accumbens $[(E / \mathrm{N}$ females $(\mathrm{p} \leq 0.05)$, vehicle-treated males $(\mathrm{p} \leq 0.01)$, and vehicle-treated females $(p \leq 0.05)]$ and hippocampus $[(E / N$ females $(p \leq 0.01)$, vehicle-treated males ( $\mathrm{p} \leq 0.01)$, and vehicle-treated females $(\mathrm{p} \leq 0.01)]$. Males from both control and treatment groups also had more OT receptor binding than females in the ventromedial hypothalamus [F $(1,21)=6.061, p \leq 0.01]$. There were no differences in any of the other regions assessed.

\section{Discussion}

As an extension of our previous work, we predicted that simultaneous prenatal exposure to both ethanol and nicotine would sex-specifically increase adult ethanol consumption after being primed during adolescent drinking, and that decreased OT mRNA expression or receptor binding would be associated with this behavioral change. Our data indicate that there are sexspecific effects on ethanol consumption and preference during adolescence and adulthood. The interaction of the stimulant properties of nicotine and depressant properties of ethanol on the central nervous system during development resulted in fewer behavioral consequences than has been found with ethanol or nicotine alone; thus, the mechanism of this interaction is 
interesting in terms of potential interventions and our understanding of how these drugs exert their teratogenic effects.

Our findings on $\mathrm{E} / \mathrm{N}$ dam weight gain and $\mathrm{E} / \mathrm{N}$ litter weight, however, parallels human and animal research reporting that exposure to ethanol and/or nicotine led to less weight gain in the mother and lower overall birth weight $[19,45,50,62,64]$. Interestingly, at all time points the weight disparity between controls and $\mathrm{E} / \mathrm{N}$ offspring continued to increase, potentially resulting from permanent damage to growth factor regulation following prenatal ethanol exposure [43]. Although gestational nicotine treatment has been shown to have no effect on crouching behavior [70], it is also possible that continued administration of nicotine during the first few days of lactation reduced milk production through decreased prolactin secretion [68], and offspring experienced less growth in the early postnatal period [28]. Unfortunately, weight gain of pups during the first week was not measured and will be an interesting phenomenon to investigate in the future. We recently reported that $\mathrm{E} / \mathrm{N}$ dams raising surrogate pups show primarily non pup-directed deficits in maternal behavior on postpartum day one [45], suggesting that pups reared by their own biological dams may not suffer from overt maternal neglect as do those reared by mothers with deficits in nursing or licking [31,32]. However, it is possible that maternal behavior and feeding was less than optimal in the later postpartum period, especially if nicotine withdrawal occurred, which could have potentially impacted pup development. This has not been directly tested here and should be considered in future studies.

We expected that offspring of the E/N-treated dams would display a higher preference for ethanol as adolescents and adults, given that both nicotine or ethanol exposure alone are reported to increase later responding to each drug respectively [2,4,8,12,19,37]. Our results indicated that, aside from decreased weight gain, prenatal $\mathrm{E} / \mathrm{N}$ exposure had only minor effects on drinking behavior and preference at adolescence (PND 30-44). In our previous study we found that prenatal E/N exposure was associated with an increase in the sex differences in ethanol consumption during adolescence [45]; however, the acquisition phase to ethanol used in that study did not include the step-up procedure, which may have impacted the animal's first experience with ethanol consumption differently. The few studies that have examined sex differences in ethanol drinking behavior during adolescence suggest that females drink more ethanol than males [16,69], although none of these studies used a forced ethanol exposure. Sprague-Dawley rats may not spontaneously consume ethanol solutions during the acquisition phase, therefore the forced consumption ensures experience with ethanol prior to the two-bottle choice phase. This phase of testing may impact the differences in ethanol consumption seen between the sexes.

During adulthood, vehicle-treated females drank more ethanol than all groups including vehicle-treated males and $\mathrm{E} / \mathrm{N}$ females. Females typically have higher ethanol consumption and preference measures compared to males in adult rat models [3,58], indicating our vehicle treatment did not disrupt this naturally occurring behavioral difference during adulthood. Interestingly, E/N treatment reduced this sex difference in ethanol consumption during acquisition and forced consumption, and abolished the sex difference during the two-bottle choice phase. Forced ethanol exposure in adolescence may lead to an ethanol aversion experienced more strongly by E/N females, who consumed less ethanol than adult vehicletreated females. The forced consumption phase was likely stressful, and females are more sensitive to effects of prenatal ethanol exposure on behavioral stress and hypothalamicpituitary-adrenal response [72], possibly leading to the observed reduced ethanol preference during adulthood $[1,12,39]$.

Prior reports indicate that adolescent male animals consume higher quantities of ethanol and exhibit greater ethanol preference compared to adults $[69,73]$. We found that in all groups, except vehicle-treated females, adolescents drank more than adults during acquisition and 
forced consumption, but no differences were observed in the two-bottle choice phase of testing, highlighting another difference between $\mathrm{E} / \mathrm{N}$ and vehicle-treated females. Additionally, these results highlight normal sex differences in ethanol consumption following prior experience with ethanol during adolescence. The differences in ethanol consumption are not a result of changes in normal taste preferences or consumption of a natural reinforcer, as groups did not differ in their saccharin consumption on either test day (PND 30 or PND 60) indicating that any differences observed were specific to ethanol consumption.

The results of this study were surprising given the numerous studies showing increased drugseeking behavior following prenatal exposure; however, controversy exists over whether or not prenatal exposure to drugs of abuse actually increases drug-seeking behavior during adolescence and adulthood [12,39], especially in Sprague-Dawley rats, which may be resistant to ethanol-induced behavioral teratogenesis [12]. Ethanol's teratogenic effects are dosedependent [63], and based on similar ethanol liquid diet studies, BEC values around 130-150 $\mathrm{mg} / \mathrm{dl}$ were expected during gestation [67]; however, in our study, dams had lower than anticipated BECs. Possibly these dams did not consume as much diet as rats in other studies, although this is hard to determine from the literature. The dams may have obtained a smaller functional dose of ethanol since acute nicotine can lower peak BECs following ethanol ingestion in both adult female [55] and neonatal rats [11], although the effects of chronic nicotine on BEC are unknown.

Both prenatal nicotine and prenatal alcohol exposure can negatively impact the cholinergic system [2,49], sometimes sex-specifically [65], and the emerging role of $\alpha 4 \beta 2$ nicotinic acetylcholine receptors in ethanol drinking [17,18], implicates this as a possible mechanism for these results. This avenue is currently being investigated by the lab. Alternatively, combined exposure to ethanol and nicotine throughout gestation could have very different effects on the developing nervous system than either drug alone, and these plausible causes warrant future investigations.

Given recent reports of neuropeptides influencing addictive behavior [9], particularly in socially-facilitating environments [44], and our recent finding that ventral tegmental area OT levels are inversely related to drinking behavior in males, while directly related in females [45], we believe it is important to consider oxytocin's potential role in addiction. We assessed OT receptor binding and mRNA expression in several brain regions, as we expected that differences in ethanol preference would be associated with OT production or binding in regions involved in reward behavior. E/N exposure had little effect on oxytocin mRNA production, but was associated with increased OT receptor binding in the nucleus accumbens and CA3 region of the hippocampus of males only.

Higher levels of OT receptor binding in the nucleus accumbens in $\mathrm{E} / \mathrm{N}$ males could have interesting implications for differences seen during the acquisition phase of ethanol preference testing in adulthood, as $\mathrm{E} / \mathrm{N}$ males consumed less ethanol than all other groups (ns). Given the known role of the nucleus accumbens in motivation toward a reward [15], and OT's involvement in behavioral response to drugs of abuse [35,61], greater OT receptor binding may inhibit the development of tolerance to ethanol consumption during the acquisition period. Oxytocin receptor binding was assessed following adult testing thus it is unclear whether these differences would have been present before or following adolescent testing or in particular phases of testing. The shell and the core of the nucleus accumbens were analyzed together since there is no difference in OT receptor binding between the core and shell $[53,54]$. The differences observed in OT receptor binding could be a consequence of abnormally high or low levels of OT in response to the experimental procedures, and this questions needs to be addressed in future studies. Unfortunately, nucleus accumbens OT levels were not assessed in 
the previous study, so whether there is a similar relation to drinking behaviors, as seen in the VTA, is currently unknown.

Males showed higher OT receptor binding in the ventromedial hypothalamus, which plays a key role both in fluid consumption and sexual behavior, and these sex differences in OT binding are in agreement with other studies [6,7]. We did not anticipate treatment differences in these areas, unless the animals had suffered from dehydration. OT signaling can increase transiently following severe dehydration [14], however; OT receptor binding appears insensitive to the increased water consumption seen in $\mathrm{E} / \mathrm{N}$ offspring in this study. These results, in conjunction with those mentioned above, suggest that prenatal exposure to ethanol and nicotine can impact sex-specific oxytocin receptor signaling in a brain-region specific manner.

The present study was designed as a more translational preclinical exposure model since concurrent use of both nicotine and alcohol is more common than isolated use in the human population. Our findings provide an interesting platform to begin mechanistic studies of ethanol and nicotine only groups to determine how prenatal exposure to either drug alone may alter sex-specific differences in ethanol or nicotine preference and OT's role in potential behavioral changes. We did not have separate ethanol only, nicotine only or chow-fed comparison groups, which could be seen as a limitation, although it was not practical for us to do separate drug group studies before assessing results of the combined drug model. The impact on the fetus of any malnutrition caused by the pair-feeding procedure varies across reports, with several studies showing no difference between offspring whose dams were pair-fed compared to offspring whose dams had ad libitum access to food [67,75,77,78]. We felt that given the extensive literature published on the effects of prenatal exposure to either drug alone, the paucity of studies investigating their interaction, and the clinical relevance of concurrent ethanol and nicotine use and abuse, we were justified in doing these initial studies focused primarily on determining if concurrent drug treatment differed from control treatment.

An unexpected outcome of this study was having only nicotine exposure during the first neonatal week through the dam's milk. We originally planned to continue the ethanol treatment of the dams into the postpartum period for the remaining days that pups were exposed to nicotine, but found that pup survival dropped significantly using that procedure. This finding necessitated that we switch to a pellet diet for treatment and control dams at delivery since pups in this study were reared by their natural dams. Whether nicotine exposure alone may have impacted later behavior is unclear, although there are no similar studies we are aware of for comparison. Future mechanistic studies may allow us to answer questions about whether nicotine alone during this developmental time affects later drug preference or OT.

Understanding the impact of these findings must be considered with the greater literature about ethanol and nicotine's separate effects on the developmental time points which were administered here.

This study indicates primarily that combined ethanol and nicotine effects on ethanol preference occur in a sex-specific manner and have less impact on preference in comparison to other reports of either alone, and on OT, which has not been systematically studied in other models. These findings highlight the potential of future mechanistic studies to determine the action of nicotine and oxytocin in regards to the mediation of the teratological effects of ethanol exposure.

\section{Acknowledgments}

This work was supported by the NIDA (RO1-DA13283), the NIAAA (AA11605-10) and the UNC Bowles Center for Alcohol Studies. 
This work was supported by the National Institutes on Drug Abuse (R01-DA-13283 awarded to JMJ), and a pilot grant from the UNC Bowles Center for Alcohol Studies and NIAAA (AA11605).

\section{References}

1. Abate P, Pueta M, Spear NE, Molina JC. Fetal learning about ethanol and later ethanol responsiveness: evidence against "safe" amounts of prenatal exposure. Exp Biol Med (Maywood) 2008;233:139-154. [PubMed: 18222969]

2. Abreu-Villaca Y, Seidler FJ, Tate CA, Cousins MM, Slotkin TA. Prenatal nicotine exposure alters the response to nicotine administration in adolescence: effects on cholinergic systems during exposure and withdrawal. Neuropsychopharmacol 2004;29:879-890.

3. Almeida OF, Shoaib M, Deicke J, Fischer D, Darwish MH, Patchev VK. Gender differences in ethanol preference and ingestion in rats. The role of the gonadal steroid environment. J Clin Invest 1998;101:2677-2685. [PubMed: 9637701]

4. Arias C, Chotro MG. Increased preference for ethanol in the infant rat after prenatal ethanol exposure, expressed on intake and taste reactivity tests. Alcohol Clin Exp Res 2005;29:337-346. [PubMed: 15770108]

5. Baer JS, Sampson PD, Barr HM, Connor PD, Streissguth AP. A 21-year longitudinal analysis of the effects of prenatal alcohol exposure on young adult drinking. Arch Gen Psychiatry 2003;60:377-385. [PubMed: 12695315]

6. Bale TL, Dorsa DM. Sex differences in and effects of estrogen on oxytocin receptor messenger ribonucleic acid expression in the ventromedial hypothalamus. Endocrinology 1995;136:27-32. [PubMed: 7828541]

7. Bale TL, Pedersen CA, Dorsa DM. CNS oxytocin receptor mRNA expression and regulation by gonadal steroids. Adv Exp Med Biol 1995;395:269-280. [PubMed: 8713977]

8. Bond NW, Di Giusto EL. Effects of prenatal alcohol consumption on open-field behaviour and alcohol preference in rats. Psychopharmacologia 1976;46:163-165. [PubMed: 951453]

9. Boutrel B. A neuropeptide-centric view of psychostimulant addiction. Br J Pharmacol 2008;22:343357. [PubMed: 18414383]

10. Centers for Disease Control and Prevention. Alcohol Consumption Among Women Who Are Pregnant or Who Might Become Pregnant - United States, 2002. Morbidity and Mortality Weekly Report 2004;53:1178-1181. [PubMed: 15614234]

11. Chen WJ, Parnell SE, West JR. Nicotine decreases blood alcohol concentration in neonatal rats. Alcohol Clin Exp Res 2001;25:1072-1077. [PubMed: 11505035]

12. Chotro MG, Arias C, Laviola G. Increased ethanol intake after prenatal ethanol exposure: Studies with animals. Neurosci Biobehav Rev 2007;31:181-191. [PubMed: 17010438]

13. Christ, B.; Clascá, F.; Fahrenkrug, J.; Haines, DE.; Hannibal, J.; Korf, H-W.; Kummer, D.; Marani, E.; Putz, R.; Sano, Y.; Schiebler, TH.; Zilles, K. Neuronal Input Pathways to the Brain's Biological Clock and their Functional Significance. Springer; Germany: 2006.

14. da Silveira LT, Junta CM, Monesi N, Oliveira-Pelegrin GR, Passos GA, Rocha MJ. Time Course of c-fos, vasopressin and oxytocin mRNA Expression in the Hypothalamus Following Long-Term Dehydration. Cell Mol Neurobiol. 2007

15. Di Chiara G. Nucleus accumbens shell and core dopamine: differential role in behavior and addiction. Behav Brain Res 2002;137:75-114. [PubMed: 12445717]

16. Doremus TL, Brunell SC, Rajendran P, Spear LP. Factors influencing elevated ethanol consumption in adolescent relative to adult rats. Alcohol Clin Exp Res 2005;29:1796-1808. [PubMed: 16269909]

17. Ericson M, Lof E, Stomberg R, Chau P, Soderpalm B. Nicotinic acetylcholine receptors in the anterior, but not posterior, ventral tegmental area mediate ethanol-induced elevation of accumbal dopamine levels. J Pharmacol Exp Ther 2008;326:76-82. [PubMed: 18369179]

18. Ericson M, Molander A, Lof E, Engel JA, Soderpalm B. Ethanol elevates accumbal dopamine levels via indirect activation of ventral tegmental nicotinic acetylcholine receptors. Eur J Pharmacol 2003;467:85-93. [PubMed: 12706460]

19. Ernst M, Moolchan ET, Robinson ML. Behavioral and neural consequences of prenatal exposure to nicotine. J Am Acad Child Adolesc Psychiatry 2001;40:630-641. [PubMed: 11392340] 
20. Falk DE, Yi HY, Hiller-Sturmhofel S. An epidemiologic analysis of co-occurring alcohol and tobacco use and disorders: findings from the National Epidemiologic Survey on Alcohol and Related Conditions. Alcohol Res Health 2006;29:162-171. [PubMed: 17373404]

21. Finer LB, Henshaw SK. Disparities in rates of unintended pregnancy in the United States, 1994 and 2001. Perspect Sex Reprod Health 2006;38:90-96. [PubMed: 16772190]

22. Fish EW, Shahrokh D, Bagot R, Caldji C, Bredy T, Szyf M, Meaney MJ. Epigenetic Programming of Stress Responses through Variations in Maternal Care. Ann N Y Acad Sci 2004;1036:167-180. [PubMed: 15817737]

23. Francis DD, Young LJ, Meaney MJ, Insel TR. Naturally occurring differences in maternal care are associated with the expression of oxytocin and vasopressin (V1a) receptors: gender differences. J Neuroendocrinol 2002;14:349-353. [PubMed: 12000539]

24. Gimpl G, Fahrenholz F. The oxytocin receptor system: structure, function, and regulation. Physiol Rev 2001;81:629-683. [PubMed: 11274341]

25. Goodlett CR, Horn KH, Zhou FC. Alcohol teratogenesis: mechanisms of damage and strategies for intervention. Exp Biol Med (Maywood) 2005;230:394-406. [PubMed: 15956769]

26. Goodwin RD, Keyes K, Simuro N. Mental disorders and nicotine dependence among pregnant women in the United States. Obstet Gynecol 2007;109:875-883. [PubMed: 17400849]

27. Guyer B, Hoyert DL, Martin JA, Ventura SJ, MacDorman MF, Strobino DM. Annual summary of vital statistics--1998. Pediatrics 1999;104:1229-1246. [PubMed: 10585972]

28. Hamosh M, Simon MR, Hamosh P. Effect of nicotine on the development of fetal and suckling rats. Biol Neonate 1979;35:290-297. [PubMed: 476202]

29. Hanley JA, Negassa A, Edwardes MD, Forrester JE. Statistical analysis of correlated data using generalized estimating equations: an orientation. Am J Epidemiol 2003;157:364-375. [PubMed: 12578807]

30. Jarrett TM, McMurray MS, Walker CH, Johns JM. Cocaine treatment alters oxytocin receptor binding but not mRNA production in postpartum rat dams. Neuropeptides 2006;40:161-167. [PubMed: 16677710]

31. Johns JM, Elliott DL, Hofler VE, Joyner PW, McMurray MS, Jarrett TM, Haslup AM, Middleton $\mathrm{CL}$, Elliott JC, Walker $\mathrm{CH}$. Cocaine treatment and prenatal environment interact to disrupt intergenerational maternal behavior in rats. Behav Neurosci 2005;119:1605-1618. [PubMed: 16420163]

32. Johns JM, Noonan LR, Zimmerman LI, Li L, Pedersen CA. Effects of chronic and acute cocaine treatment on the onset of maternal behavior and aggression in Sprague-Dawley rats. Behav Neurosci 1994;108:107-112. [PubMed: 8192835]

33. Kampov-Polevoy AB, Garbutt JC, Janowsky DS. Association between preference for sweets and excessive alcohol intake: a review of animal and human studies. Alcohol Alcohol 1999;34:386-395. [PubMed: 10414615]

34. Klein LC, Stine MM, Pfaff DW, Vandenbergh DJ. Laternal nicotine exposure increases nicotine preference in periadolescent male but not female C57B1/6J mice. Nicotine Tob Res 2003;5:117124. [PubMed: 12745513]

35. Kovacs GL, Sarnyai Z, Szabo G. Oxytocin and addiction: a review. Psychoneuroendocrinology 1998;23:945-962. [PubMed: 9924746]

36. Lenz KM, Sengelaub DR. Maternal licking influences dendritic development of motoneurons in a sexually dimorphic neuromuscular system. Brain Res 2006;1092:87-99. [PubMed: 16674931]

37. Levin ED, Lawrence S, Petro A, Horton K, Seidler FJ, Slotkin TA. Increased nicotine selfadministration following prenatal exposure in female rats. Pharmacol Biochem Behav 2006;85:669674. [PubMed: 17196243]

38. Light KC, Grewen KM, Amico JA, Boccia M, Brownley KA, Johns JM. Deficits in plasma oxytocin responses and increased negative affect, stress, and blood pressure in mothers with cocaine exposure during pregnancy. Addict Behav 2004;29:1541-1564. [PubMed: 15451123]

39. Malanga CJ, Kosofsky BE. Does drug abuse beget drug abuse? Behavioral analysis of addiction liability in animal models of prenatal drug exposure. Brain Res Dev Brain Res 2003;147:47-57. 
40. Matta SG, Elberger AJ. Combined exposure to nicotine and ethanol throughout full gestation results in enhanced acquisition of nicotine self-administration in young adult rat offspring. Psychopharmacology (Berl) 2007;193:199-213. [PubMed: 17404712]

41. May PA, Gossage JP. Estimating the prevalence of fetal alcohol syndrome. A summary. Alcohol Res Health 2001;25:159-167. [PubMed: 11810953]

42. Mayer AD, Rosenblatt JS. A method for regulating the duration of pregnancy and the time of parturition in Sprague-Dawley rats (Charles River CD strain). Dev Psychobiol 1998;32:131-136. [PubMed: 9526688]

43. McGivern RF, Yellon SM. Delayed onset of puberty and subtle alterations in GnRH neuronal morphology in female rats exposed prenatally to ethanol. Alcohol 1992;9:335-340. [PubMed: 1637500]

44. McGregor IS, Callaghan PD, Hunt GE. From ultrasocial to antisocial: a role for oxytocin in the acute reinforcing effects and long-term adverse consequences of drug use? Br J Pharmacol 2008;154:358368. [PubMed: 18475254]

45. McMurray MS, Williams SK, Jarrett TM, Cox ET, Fay EE, Overstreet DH, Walker CH, Johns JM. Gestational ethanol and nicotine exposure: effects on maternal behavior, oxytocin, and offspring ethanol intake in the rat. Neurotoxicol Teratol 2008;30:475-486. [PubMed: 18664381]

46. Mennella JA, Pepino MY. Short-term effects of alcohol consumption on the hormonal milieu and mood states in nulliparous women. Alcohol 2006;38:29-36. [PubMed: 16762689]

47. Mennella JA, Pepino MY, Teff KL. Acute alcohol consumption disrupts the hormonal milieu of lactating women. J Clin Endocrinol Metab 2005;90:1979-1985. [PubMed: 15623810]

48. Morris M, Maconochie N, Doyle P. Does gravidity influence smoking behaviour in pregnancy? A comparison of multigravid and primigravid women. Paediatr Perinat Epidemiol 2007;21:201-209. [PubMed: 17439528]

49. Nagahara AH, Handa RJ. Loss of nicotine-induced effects on locomotor activity in fetal alcoholexposed rats. Neurotoxicol Teratol 1999;21:647-652. [PubMed: 10560771]

50. National Center on Addiction and Substance Abuse. No Safe Haven: Children of Substance-Abusing Parents. Columbia University: National Center on Addiction and Substance Abuse; Jan. 1999

51. Niccols A. Fetal alcohol syndrome and the developing socio-emotional brain. Brain Cogn 2007;65:135-142. [PubMed: 17669569]

52. Office of Applied Studies. Results from the 2006 National Survey on Drug Use and Health: National findings (DHHS Publication No. SMA 07-4293, NSDUH Series H-32). Substance Abuse and Mental Health Services Administration; Rockville, MD: 2007.

53. Olazabal DE, Young LJ. Oxytocin receptors in the nucleus accumbens facilitate "spontaneous" maternal behavior in adult female prairie voles. Neuroscience 2006;141:559-568. [PubMed: 16725274]

54. Olazabal DE, Young LJ. Species and individual differences in juvenile female alloparental care are associated with oxytocin receptor density in the striatum and the lateral septum. Horm Behav 2006;49:681-687. [PubMed: 16442534]

55. Parnell SE, West JR, Chen WJ. Nicotine decreases blood alcohol concentrations in adult rats: a phenomenon potentially related to gastric function. Alcohol Clin Exp Res 2006;30:1408-1413. [PubMed: 16899044]

56. Patra B, Overstreet DH, Rezvani AH, Cleves M, Parsian A. Analysis of alcohol-related phenotypes in $\mathrm{F} 2$ progeny derived from $\mathrm{FH} / \mathrm{Wjd}$ and $\mathrm{ACI} / \mathrm{N}$ rat strains reveals independent measures and sex differences. Behav Brain Res 2007;177:37-44. [PubMed: 17161877]

57. Paxinos, G.; Watson, C. The Rat Brain In Stereotaxic Coordinates. Vol. 3rd ed. Academic Press; San Diego: 1997.

58. Piano MR, Carrigan TM, Schwertz DW. Sex differences in ethanol liquid diet consumption in Sprague-Dawley rats. Alcohol 2005;35:113-118. [PubMed: 15963424]

59. Pitkanen T, Lyyra AL, Pulkkinen L. Age of onset of drinking and the use of alcohol in adulthood: a follow-up study from age 8-42 for females and males. Addiction 2005;100:652-661. [PubMed: 15847623] 
60. Poikolainen K, Tuulio-Henriksson A, Aalto-Setala T, Marttunen M, Lonnqvist J. Predictors of alcohol intake and heavy drinking in early adulthood: a 5-year follow-up of 15-19-year-old Finnish adolescents. Alcohol Alcohol 2001;36:85-88. [PubMed: 11139422]

61. Sarnyai Z. Oxytocin and neuroadaptation to cocaine. Prog Brain Res 1998;119:449-466. [PubMed: 10074806]

62. Sarnyai Z, Kovacs GL. Role of oxytocin in the neuroadaptation to drugs of abuse. Psychoneuroendocrinology 1994;19:85-117. [PubMed: 9210215]

63. Savage DD, Becher M, de la Torre AJ, Sutherland RJ. Dose-dependent effects of prenatal ethanol exposure on synaptic plasticity and learning in mature offspring. Alcohol Clin Exp Res 2002;26:1752-1758. [PubMed: 12436066]

64. Shu XO, Hatch MC, Mills J, Clemens J, Susser M. Maternal smoking, alcohol drinking, caffeine consumption, and fetal growth: results from a prospective study. Epidemiology 1995;6:115-120. [PubMed: 7742395]

65. Slotkin TA, Mackillop EA, Rudder CL, Ryde IT, Tate CA, Seidler FJ. Permanent, sex-selective effects of prenatal or adolescent nicotine exposure, separately or sequentially, in rat brain regions: indices of cholinergic and serotonergic synaptic function, cell signaling, and neural cell number and size at 6 months of age. Neuropsychopharmacol 2007;32:1082-1097.

66. Slotkin TA, Tate CA, Cousins MM, Seidler FJ. Prenatal nicotine exposure alters the responses to subsequent nicotine administration and withdrawal in adolescence: Serotonin receptors and cell signaling. Neuropsychopharmacol 2006;31:2462-2475.

67. Sobrian SK, Jones BL, James H, Kamara FN, Holson RR. Prenatal ethanol preferentially enhances reactivity of the dopamine D1 but not D2 or D3 receptors in offspring. Neurotoxicol Teratol 2005;27:73-93. [PubMed: 15681123]

68. Terkel J, Blake CA, Hoover V, Sawyer CH. Pup survival and prolactin levels in nicotine-treated lactating rats. Proc Soc Exp Biol Med 1973;143:1131-1135. [PubMed: 4743694]

69. Truxell EM, Molina JC, Spear NE. Ethanol intake in the juvenile, adolescent, and adult rat: effects of age and prior exposure to ethanol. Alcohol Clin Exp Res 2007;31:755-765. [PubMed: 17386073]

70. Vaglenova J, Birru S, Pandiella NM, Breese CR. An assessment of the long-term developmental and behavioral teratogenicity of prenatal nicotine exposure. Behav Brain Res 2004;150:159-170. [PubMed: 15033289]

71. Wang ZX, Liu Y, Young LJ, Insel TR. Hypothalamic Vasopressin Gene Expression Increases in Both Males and Females Postpartum in a Biparental Rodent. J Neuroendocrinol 2000;12:111-120. [PubMed: 10718906]

72. Weinberg J, Sliwowska JH, Lan N, Hellemans KG. Prenatal alcohol exposure: foetal programming, the hypothalamic-pituitary-adrenal axis and sex differences in outcome. J Neuroendocrinol 2008;20:470-488. [PubMed: 18266938]

73. Wills TA, Knapp DJ, Overstreet DH, Breese GR. Differential dietary ethanol intake and blood ethanol levels in adolescent and adult rats: effects on anxiety-like behavior and seizure thresholds. Alcohol Clin Exp Res 2008;32:1350-1360. [PubMed: 18540921]

74. Windle RJ, Shanks N, Lightman SL, Ingram CD. Central oxytocin administration reduces stressinduced corticosterone release and anxiety behavior in rats. Endocrinology 1997;138:2829-2834. [PubMed: 9202224]

75. Youngentob SL, Molina JC, Spear NE, Youngentob LM. The effect of gestational ethanol exposure on voluntary ethanol intake in early postnatal and adult rats. Behav Neurosci 2007;121:1306-1315. [PubMed: 18085883]

76. Zeger SL, Liang KY. Longitudinal data analysis for discrete and continuous outcomes. Biometrics 1986;42:121-130. [PubMed: 3719049]

77. Zhou FC, Sari Y, Powrozek TA. Fetal alcohol exposure reduces serotonin innervation and compromises development of the forebrain along the serotonergic pathway. Alcohol Clin Exp Res 2005;29:141-149. [PubMed: 15654302]

78. Zimmerberg B, Weston HE. Postnatal stress of early weaning exacerbates behavioral outcome in prenatal alcohol-exposed juvenile rats. Pharmacol Biochem Behav 2002;73:45-52. [PubMed: 12076723] 


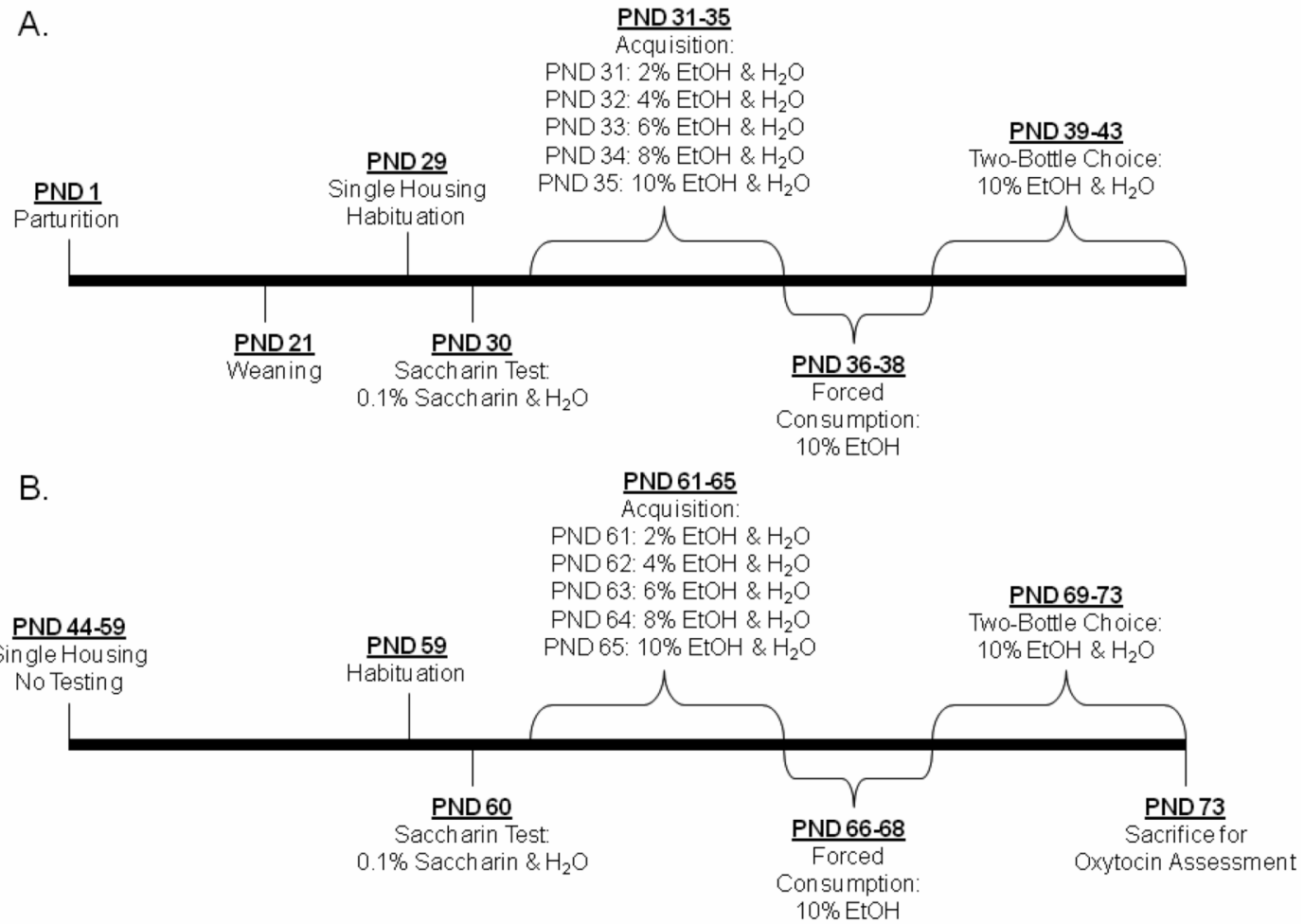

Figure 1. Ethanol Consumption Tesing Schedule

Offspring Testing Schedule. Single housing began one day prior to initiation of adolescent ethanol preference testing and continued through adult testing. Each test consisted of 4 periods: Saccharin Test, Acquisition, Forced Consumption, and Two-Bottle Choice. Testing Procedures were identical during adolescence (a.) and adulthood (b.). EtOH: ethanol solution. PND: postnatal day 
A.

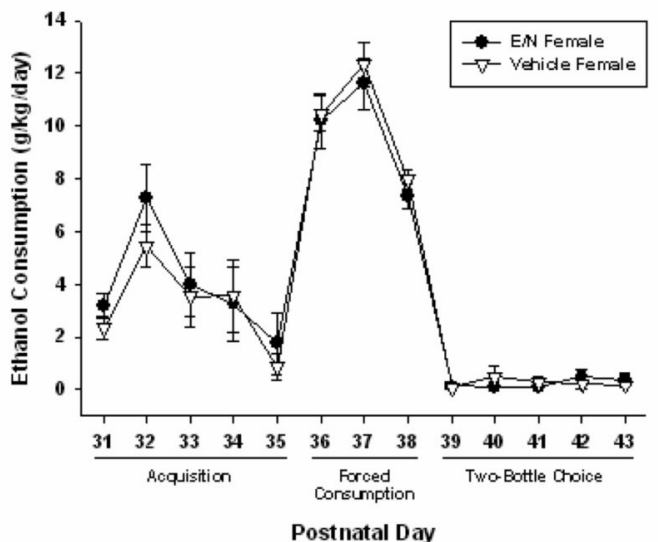

C.

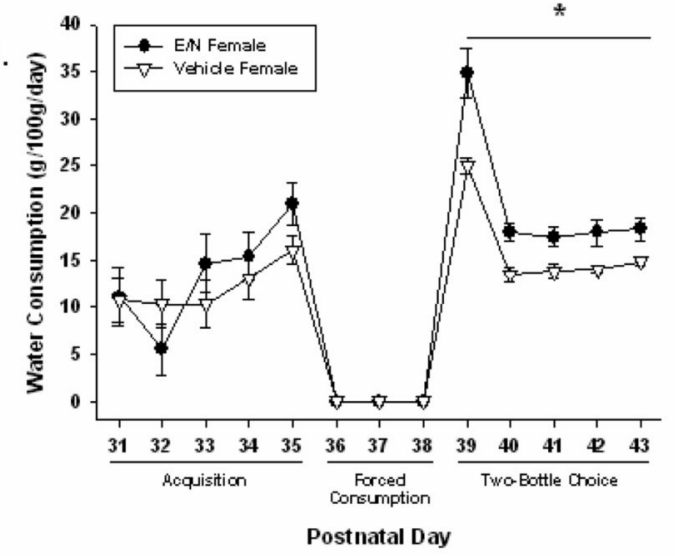

B.

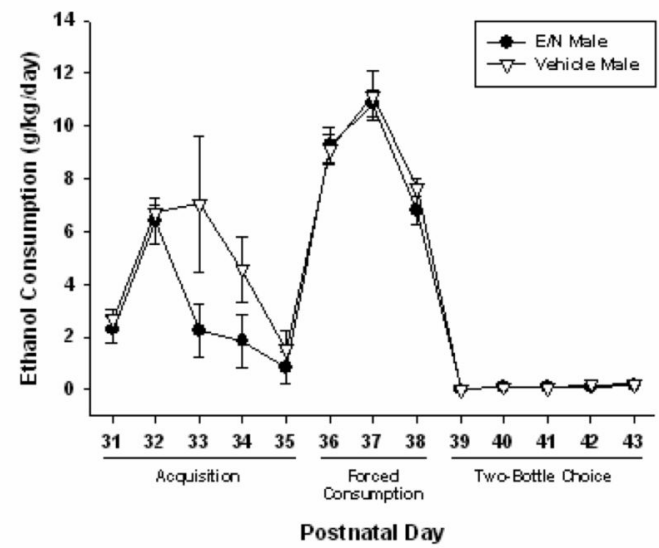

D.

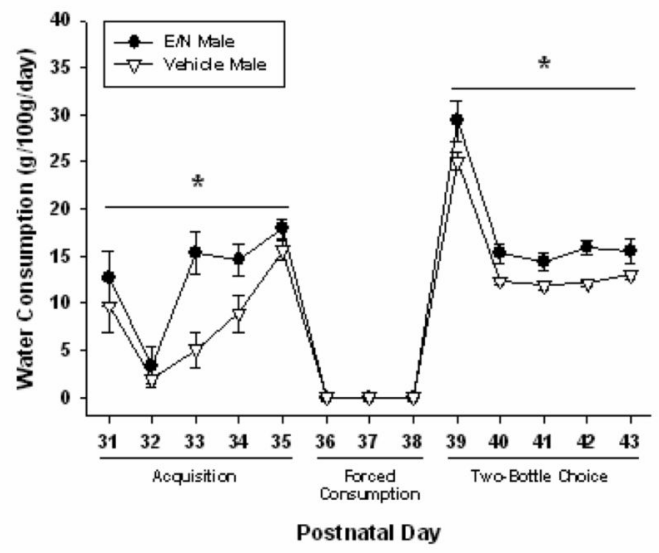

Figure 2. Group Ethanol and Water Consumption in Adolescent Offspring

Adolescent Consumption Results are presented using between group comparisons. All results are presented as means \pm SEM for every day of testing. Daily values were averaged for consumption across test periods. Significant differences are indicated as lines with asterisks $(\mathrm{p} \leq 0.05)$. a) Female Ethanol Consumption ( $\mathrm{g} / \mathrm{kg} /$ day) b) Male Ethanol Consumption $(\mathrm{g} / \mathrm{kg} /$ day) c) Female Water Consumption (g/100g/day) d) Male Water Consumption (g/100g/day). $\mathrm{E} / \mathrm{N}$ : Offspring treated with ethanol and nicotine. 

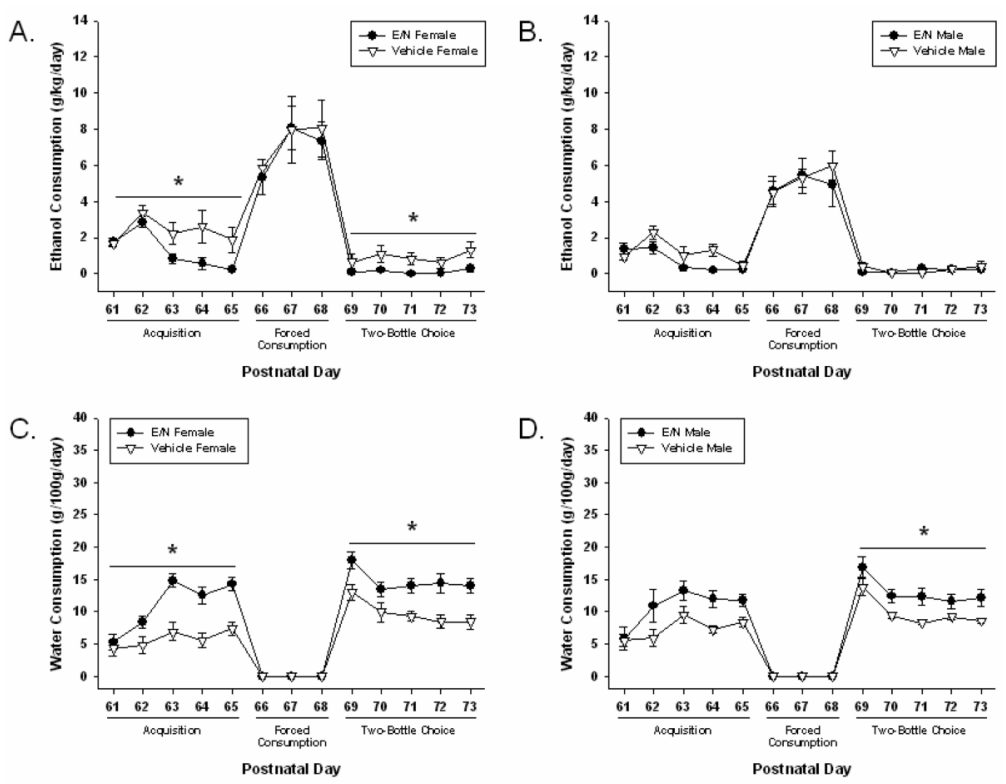

Figure 3. Group Ethanol and Water Consumption in Adult Offspring

Adult Consumption Results are presented using between group comparisons. All results are presented as means \pm SEM for every day of testing. Daily values were averaged for consumption across test periods. Significant differences are indicated as lines with asterisks $(\mathrm{p} \leq 0.05)$. a) Female Ethanol Consumption (g/kg/day) b) Male Ethanol Consumption (g/kg/ day) c) Female Water Consumption (g/100g/day) d) Male Water Consumption (g/100g/day). $\mathrm{E} / \mathrm{N}$ : Offspring treated with ethanol and nicotine. 

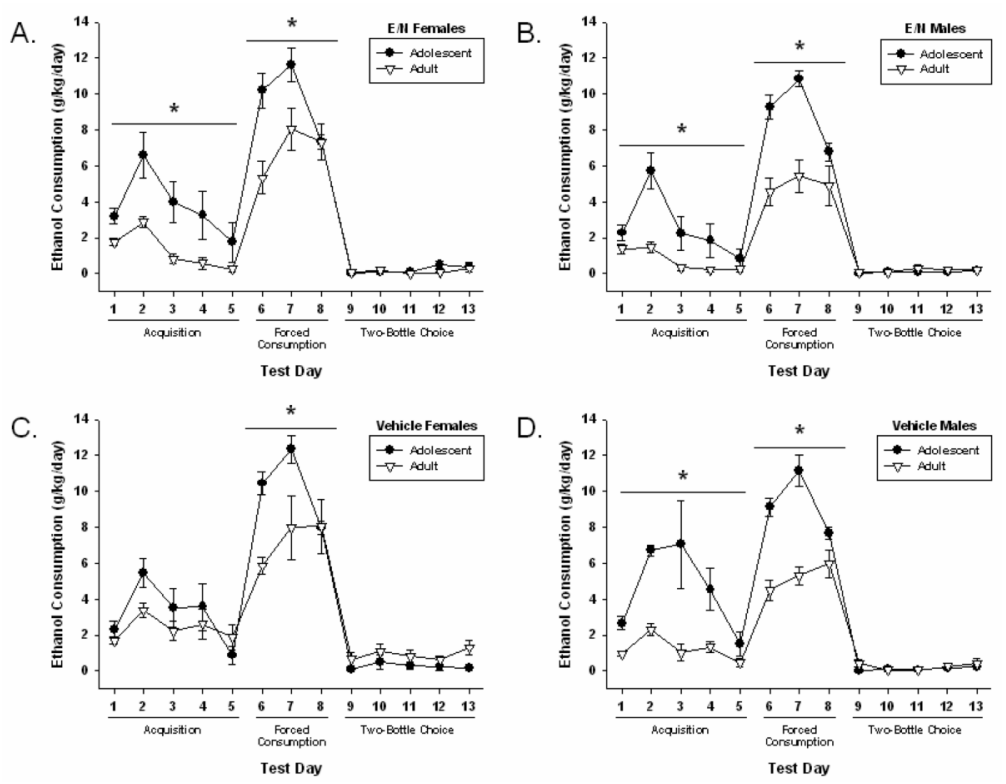

Figure 4. Within Group Age Comparisons of Ethanol and Water Consumption Age Comparison Results are presented as using between group comparisons. All results are presented as means \pm SEM for every day of testing. Daily values were averaged for consumption across test periods. Significant differences are indicated as lines with asterisks ( $\mathrm{p} \leq 0.05)$. a) E/N females b) E/N males c) Vehicle-treated females d) Vehicle-treated males. E/ $\mathrm{N}$ : Offspring treated with ethanol and nicotine. 

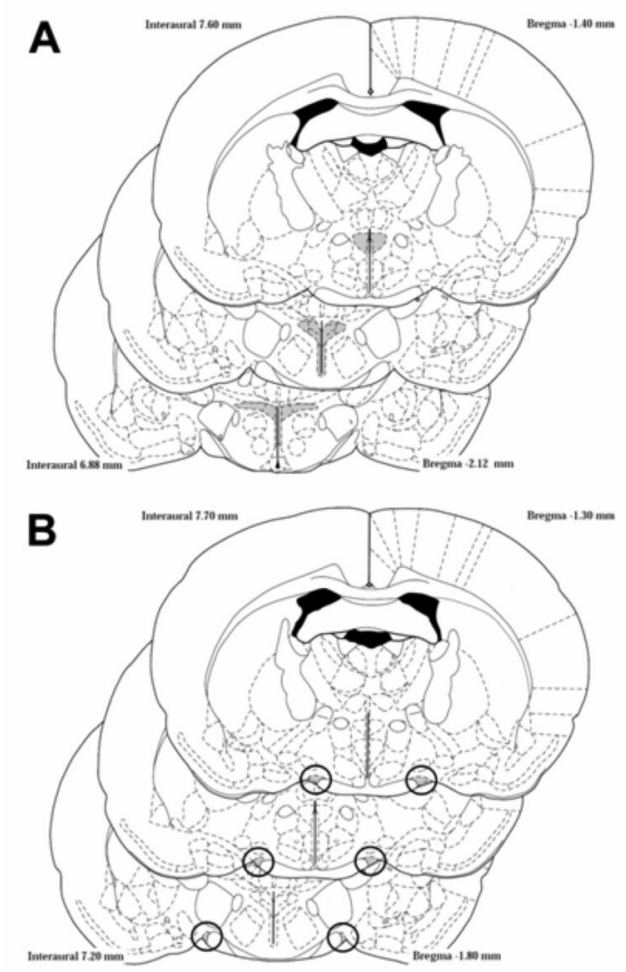

C.

E/N Female Vehicle Female

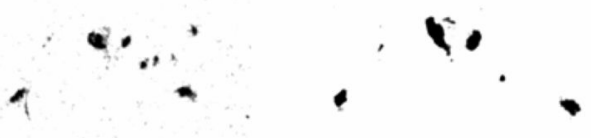

E/N Male

Vehicle Male

D.
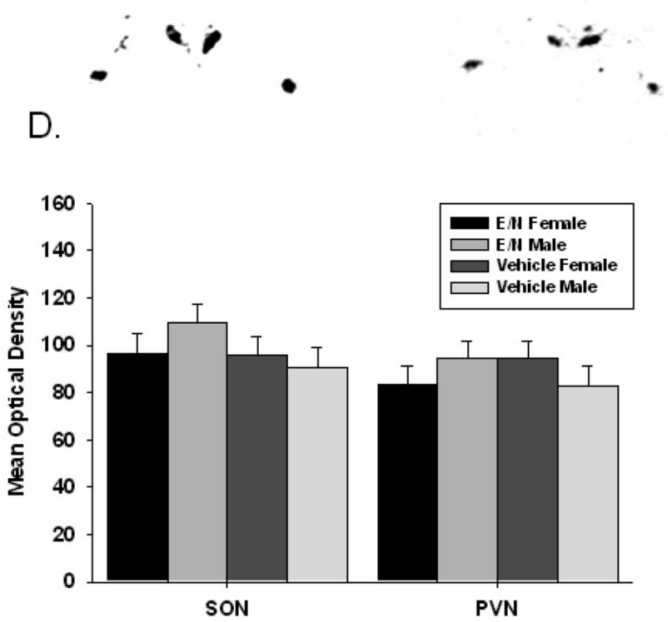

Figure 5. Adult Oxytocin mRNA In Situ Hybridization

Adult Oxytocin mRNA In Situ Hybridization. Regions that were assessed for hybridization are marked in gray for the A. paraventricular nucleus (PVN); and B. supraoptic nucleus (SON); C. Representative images from one $\mathrm{E} / \mathrm{N}$ female, $\mathrm{E} / \mathrm{N}$ male, vehicle-treated female, and vehicletreated male.; D. Quantified optical densities are presented as means \pm SEM. 
A.

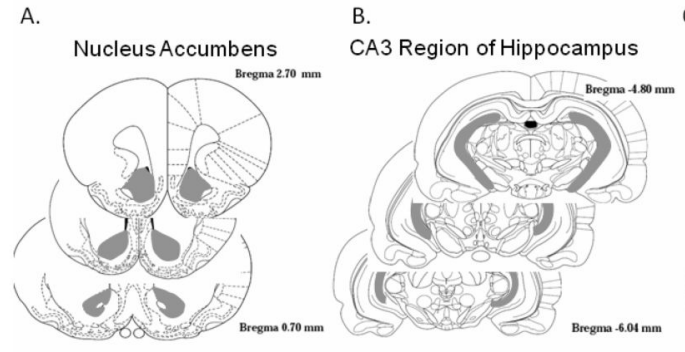
Ventromedial Hypothalamus

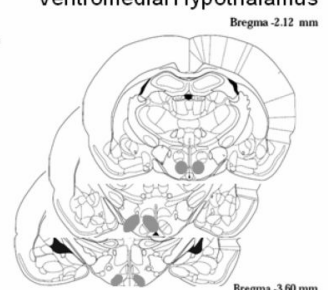

D.

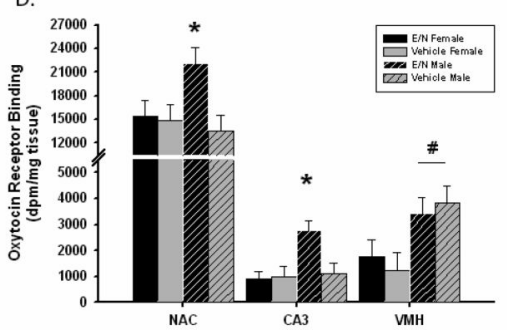

Figure 6. Adult Oxytocin Receptor Binding

Adult Oxytocin Receptor Binding. Regions that were assessed for hybridization are marked in gray for the A. nucleus accumbens (NAC); B. posterior CA3 region of hippocampus (CA3). ; C. ventromedial hypothalamus $(\mathrm{VMH}) ; \mathrm{D}$. Autoradiography analysis presented in means \pm SEM for regions with significant differences. Asterisks (*) indicate significantly above all other groups at $\mathrm{p} \leq 0.05$. \# indicates males had higher binding than females at $\mathrm{p} \leq 0.05$. 
Table 2

Individual Offspring Weight and Growth

\begin{tabular}{|c|c|c|c|c|}
\hline Group & Vehicle Females & E/N Females & Vehicle Males & E/N Males \\
\hline $\mathbf{n}$ & 12 & 14 & 12 & 14 \\
\hline $\begin{array}{l}\text { PND } 30 \\
\text { Weight }\end{array}$ & $78.90 \pm 3.2^{\dagger}$ & $67.00 \pm 3.7^{* \dagger}$ & $84.00 \pm 3.20$ & $73.50 \pm 4.00^{*}$ \\
\hline $\begin{array}{l}\text { PND } 43 \\
\text { Weight }\end{array}$ & $168.56 \pm 6.08^{\dagger}$ & $152.00 \pm 6.9^{* \dagger}$ & $218.11 \pm 6.08$ & $196.00 \pm 7.44^{*}$ \\
\hline $\begin{array}{c}\text { Adolescent } \\
\text { Weight } \\
\text { Gain }\end{array}$ & $89.67 \pm 1.93^{\dagger}$ & $85.00 \pm 4.0^{* \dagger}$ & $134.11 \pm 3.61$ & $122.50 \pm 6.56^{*}$ \\
\hline $\begin{array}{l}\text { PND 60 } \\
\text { Weight }\end{array}$ & $222.20 \pm 7.60^{\dagger}$ & $211.60 \pm 7.6^{* \dagger}$ & $357.00 \pm 7.60$ & $322.20 \pm 8.00^{*}$ \\
\hline $\begin{array}{l}\text { PND 73 } \\
\text { Weight }\end{array}$ & $273.10 \pm 10.80^{\dagger}$ & $245.40 \pm 10.1^{* \dagger}$ & $463.80 \pm 10.80$ & $406.40 \pm 11.40^{*}$ \\
\hline $\begin{array}{c}\text { Adult } \\
\text { Weight } \\
\text { Gain }\end{array}$ & $50.50 \pm 9.81^{\dagger}$ & $35.10 \pm 2.9^{* \dagger}$ & $104.80 \pm 15.46$ & $86.67 \pm 4.70^{*}$ \\
\hline
\end{tabular}

All data are presented as means \pm SEM. ANOVAs were used to analyze results. PND: Postnatal Day.

* indicates significantly less than vehicle group

${ }^{\dagger}$ indicates significantly less than males 


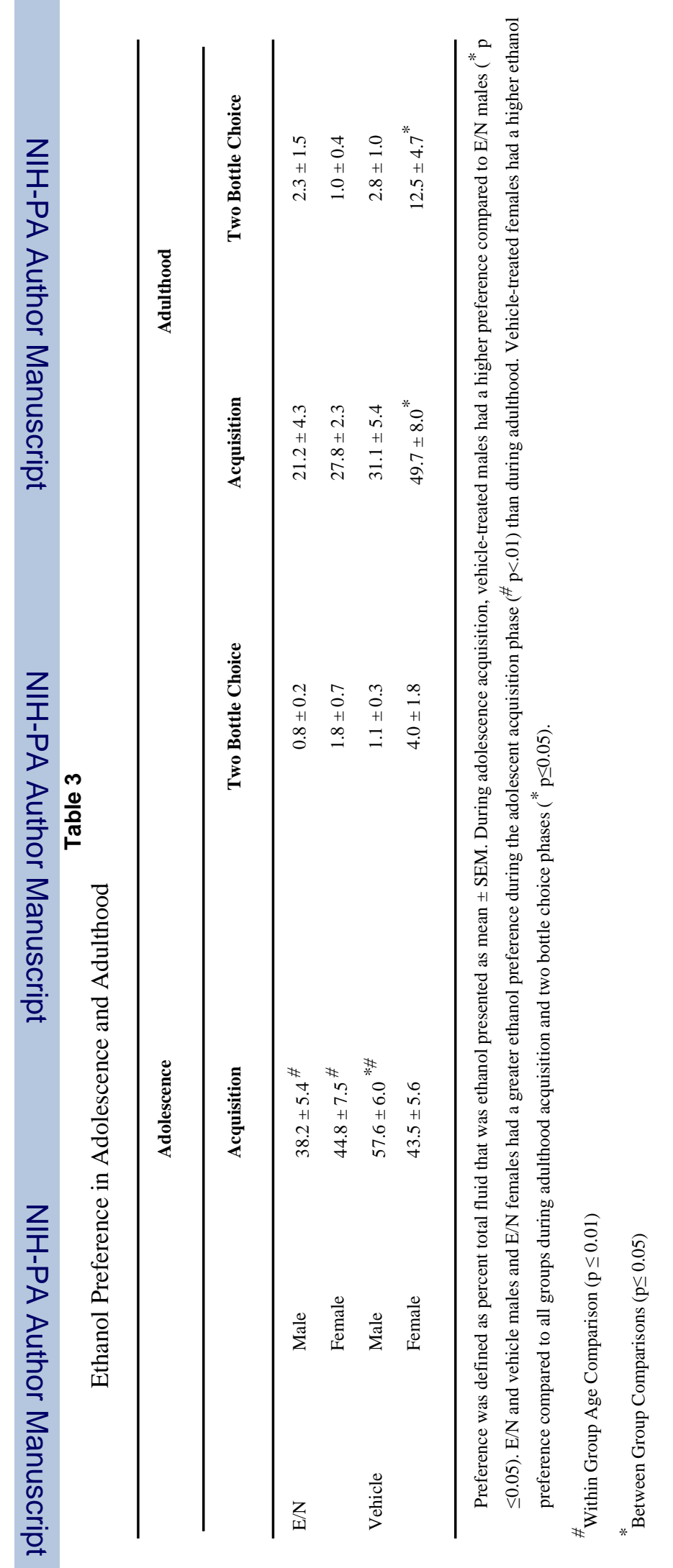

